\title{
Ichthyofaunic Inventory and Fish Landings of Lom Pangar Hydropower Dam Reservoir in the Eastern Region of Cameroon
}

\author{
Achille Njomoue Pandong1, Bruno Thierry Nyatchouba Nsangue'2, Ekmon Mbangue1, \\ N'Souvi Kodjo ${ }^{3}$, Maurice Vanlie Kontchou ${ }^{1}$, Asser Yoke ${ }^{4}$, Léopold Tcham1, Dieudonné Essola1, \\ Micah Adekunle David 5
}

\author{
${ }^{1}$ Laboratory E3M, National High Polytechnic School of Douala, University of Douala, Douala, Cameroon \\ ${ }^{2}$ College of Marine Science, Shanghai Ocean University, Shanghai, China \\ ${ }^{3}$ College of Economics and Management, Shanghai Ocean University, Shanghai, China \\ ${ }^{4}$ Netherlands Development Organisation, SNV, Yaounde, Cameroon \\ ${ }^{5}$ College of Fisheries and Life Science, Shanghai Ocean University, Shanghai, China \\ Email: njopanac@hotmail.com
}

How to cite this paper: Pandong, A.N., Nsangue, B.T.N., Mbangue, E., Kodjo, N., Kontchou, M.V., Yoke, A., Tcham, L., Essola, D. and David, M.A. (2020) Ichthyofaunic Inventory and Fish Landings of Lom Pangar Hydropower Dam Reservoir in the Eastern Region of Cameroon. Open Journal of Marine Science, 10, 245-259.

https://doi.org/10.4236/ojms.2020.104019

Received: August 3, 2020

Accepted: October 16, 2020

Published: October 19, 2020

Copyright $\odot 2020$ by author(s) and Scientific Research Publishing Inc. This work is licensed under the Creative Commons Attribution International License (CC BY 4.0).

http://creativecommons.org/licenses/by/4.0/ (c) (i) Open Access

\begin{abstract}
The Lom Pangar hydroelectric dam project located in the eastern region of Cameroon was implemented by Electricity Development Corporation (EDC). The impoundment of the Lom Pangar dam created a large reservoir with an area $\sim 590 \mathrm{~km}^{2}$ and a useful storage capacity $\sim 6$ billion $\mathrm{m}^{3}$. Thereby, this impoundment has created favourable conditions for the proliferation of fishery resources. However, a fisheries assessment study based on fishing activities is essential to attain reliable information for implementing a management plan to achieve rational and sustainable exploitation. This study was carried out on the ichtyofaunic inventory and the assessment of fish landings in Lom Pangar hydroelectric dam reservoir from April 2016 to September 30, 2016. Three main groups of fishing gear have been identified, among which gillnets, traps and longlines occupy major fishing activities. Indeed, the spatial and landing sites surveies were conducted on species composition, size composition, and quantities of fish landed during the study period. Moreover, 37 species of fish divided into 16 families were found in seven different selected fish landing sites. Carp (Cyprinus carpio) was the major fish species abundantly caught by these fishing gears which accounted for $81.60 \%$ of the total catch, and the least species was sardine (Sardinella aurita). A total of $623,229 \mathrm{Kg}$ of fish were landed which were dominated by those of the Wami landing site with 480,773 Kg representing $76.96 \%$ of the total landed catches. The smallest species caught was the white carp $(7 \mathrm{~cm})$ while the longest one was the catfish $(71$ $\mathrm{cm})$. In addition, the species of fish in the breeding season are carp, catfish,
\end{abstract}


viper fish and red tail.

\section{Keywords}

Artisanal Fishing Gears, Ictyofaunal Inventory, Lom Pangar Hydropower Dam

\section{Introduction}

The Lom Pangar hydroelectric project in Cameroon is implemented by Electricity Development Corporation (EDC). Besides, the use of water from reservoirs for irrigation or hydroelectricity in this dam, some fishing activities take place in these water-bodies (Béné et al., 2009) [1]. However, the impoundment of the dam created favorable conditions for the proliferation of fishery resources in the reservoir. Likewise, these Lom Pangar establishment sites are not at risk of being flooded during the period of heavy rains or full flooding of the retaining dam [2]. Fishery resources are the major source of animal protein in the diet of the Cameroonian population, especially for the most disadvantage sections of the population and represent $80 \%$ of the total supply of animal proteins. Indeed, the per capita demand for fish consumption was $17.90 \mathrm{~kg}$ per year in 2013 [3] [4] [5]. As a result, fishing is very active in the country and represents an important sector both from a socio-economic and food point of view. It is organized around four branches: industrial fishing, artisanal maritime fishing, inland fishing and aquaculture. However, fish production is unable to supply the demand for fish in the country. National production remains modest and fluctuates around 180,000 tons/year, including 93,000 tons for artisanal fishing, 75,000 tons for inland fishing, 8000 tons for industrial fishing, and 1000 tons for the aquaculture. Due to the fact that this production cannot meet the national demand for fishery products, which is estimated at around 400,000 tonnes/year, the country import about 220,000 tons of fish each year, which constitutes a significant flight of capital, estimated at around 100 billion FCFA/year. In order to ensure the country's food security and maintain economic growth, Cameroon must significantly increase its fish production.

During the last decades, some researchers such as Djama and Pitcher [6] [7], Njock [8] [9], and Djama [10] [11] demonstrated that the fisheries resources of Cameroonian waters are either fully exploited or in state of overexploitation. Despite the fact that the state of exploitation of inland fisheries is poorly documented, observations have been made on the decreased in landings in most impoundments and lakes inland indicating resource depletion [12] [13] [14] [15]. In addition, ENVIREP-CAM [16] reported a decrease in fish production at the Ladgo Dam between 1990 and 1991 (11,000 t to 10,675 tonnes). This trend has remained constant and in 2004 the production value (6000 tons) was about half of its 1990's value. The same goes with the other dams. In the Lake Tchad, Onuoha [17] indicated a decrease in resources due to many factors including 
overexploitation. This downward trend in production is an indication of overexploitation. The sustainable management of these resources requires upstream scientific research. Hence a downward trend in fish catches due to overfishing, intensive fishing pressure, repeated and confined use of fishing grounds in a particular area [18]. In this context, the dam reservoir of Lom Pangar can constitutes an important source of increase in fish production of the country. Rational exploitation of these resources requires the establishment of a real fisheries development policy focused on the sustainable management of the fishery resources of the reservoir. Indeed, fisheries assessment study based on the fishing activities is essential to attain reliable information for constructing a management plan to achieve rational and sustainable exploitation [5] [18] [19] [20]. In order to obtain data that are much more reliable and capable of providing relevant information, seasonal spatial and landing site surveys should be set up. Taking all this aspects into account including the lack of reported data to ensure the perfect facilitation of artisanal fisheries in the reservoir, the present study was undertaken to investigate the types and characteristics of artisanal fishing gear exploited in the Lom Pangar dam reservoir, their catch and size composition in order to estimate the overall fish production of the reservoir.

\section{Materials and Methods}

\subsection{Study Area}

The study was conducted in Lom Pangar hydropower dam reservoir in the eastern region of Cameroon. The partial impoundment of the dam created a reservoir with an area around $590 \mathrm{~km}^{2}$ and a useful storage capacity around 6 billion $\mathrm{m}^{3}$. In the present study, seven (7) fish landing sites were mostly used by fishermen to land the catch. Likewise, these sites are not susceptible to flooding during the period of heavy rains or full flooding of the dam as shown in Figure 1.

\subsection{Data Collection}

Primary data was collected by field survey which involved the investigation of the study areas in terms of artisanal marine fishing gears, quantities, species and size composition of fish landed. Data was collected from April 30 to September 30, 2016 at each of the seven sites, where a total of 493 fishermen were interviewed with a combination of field surveys, questionnaire interviews and participatory rural appraisal methods, and focus group discussion. The data was collected at each site by a facilitator from the Netherlands Development Organization (SNV-Cameroon). The taxonomic keys of Lower Guinea proposed by Stiassny et al. [21] were used to determine the families of the different species of fish caught on the landing sites.

The fish observed were identified at the species level according to Froese and Pauly [22]. Fish were weighed at each site using a load cell and then measured using an ichthyometer according to the guide of measurement of fishes [23]. These collected data were recorded on daily logs by boat. The anchoring time of 


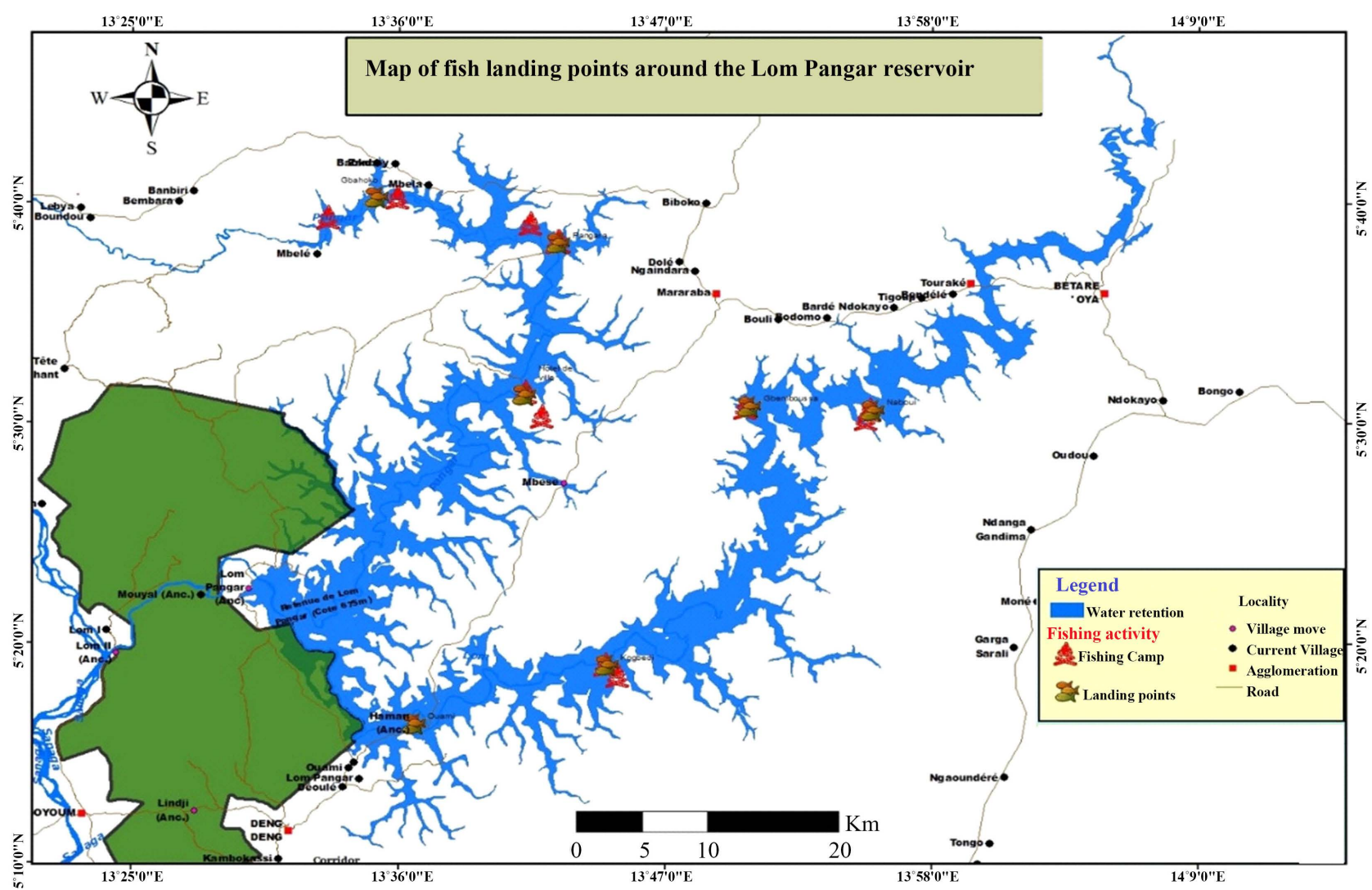

Figure 1. Distribution of deployment locations in survey of fish resources around the Lom Pangar dam reservoir.

each gear has also been estimated. The weight values of smoked and dried fish were converted to fresh fish by multiplying these values by three.

The total fish collected with carrier boats was divided by the number of fishing days to obtain the average total catch per day which was divided by the number of active fishing boats to estimate the catch per unit effort as $\mathrm{kg} / \mathrm{boat} / \mathrm{day}$. However, catch per fisherman per day (kg/fisherman/day) was calculated from the estimated daily catch per boat divided by the number of fishermen on the boat. The annual total catch from the whole lake $\left(C_{t}\right)$ was calculated as a summation of annual catch for each sub-area $\left(C_{i}\right)$, where

$$
C_{i}=\sum C_{b m} \text {. }
$$

$C_{b m}$ is the catch of each boat for each month.

$$
C_{b m}=C_{b} \times B_{s} \times D_{s} \text {. }
$$

$C_{b}$ represents the daily average catch of one boat, $B_{s}$ is the number of active fishing boats in area and $D_{s}$ is the number of active fishing days [24].

\subsection{Data Processing and Analysis Collection}

With regard to the analysis of the data collected, we used statistical processing using the online software Google Drive. However, we transferred the completed questionnaires to Google Drive which automatically generates a spreadsheet to collect the results. All primary data collected was analyzed by simple statistical 
methods using Microsoft Excel software.

\section{Results}

\subsection{Landing Sites and Fishermen}

Seven main sites for landing catches by fishermen around the reservoir have been identified: one in township Baya Mbedomo (Kogbedi) from Goura district, one in Lai (Naboui II), three in Yahoue (Gbenboussa, City Hall, Pangara) from Betare-Oya district, one in Mbitom (Gbahoko), and the last one in Kepere Deng deng (Wami) from Belabo district (Table 1). Catch data was collected from April 30 to September 30, 2016 on each site. Fishermen surveys took place at each site immediately upon landing and 493 fishermen were surveyed (Table 1). As presented in Table 1, the Wami landing site represented $40.53 \%$ of the fishermen (the greatest number of fishermen) while the Gbahoko site had the smallest number of fishermen (4.67\%).

\subsection{Fishing Gears and Methods}

Five types of fishing gears and methods were observed during the period of study: gill nets, purse seine, traps, hawk nets, and longlines. Two types of gillnets with length of $600 \mathrm{~m}$ and mesh size varying from 10 to $50 \mathrm{~mm}$ were used in the reservoir such as, the monofilament surface drifting gillnet and the fixed gillnet. Three types of longlines such as fixed, drifting and trailing longlines with hook sizes ranging from 5 to $12 \mathrm{~cm}$ were identified as being the most used in the seven sites by fishermen. However, a trailing longline with a line length of up to $1 \mathrm{~km}$ was identified at the Wami site. Two types of traps were used by fishermen, including pots and traps. However, multifilament nets such as purse seines were the least used and least known. In addition, the use of purse seines and hawks remains marginal (Figure 2). Monofilament nets are widely used in comparison to multifilament in all the fishing gear used in the seven sites. Three main types of fishing gear were identified at landing sites such as gillnets, traps and lines (Table 2). The anchoring time of fishing gear varies between 11 and 24 hours depending on the landing site of the catches (Table 1). Gillnets had the most

Table 1. Distribution of landing sites by number of fishermen surveyed.

\begin{tabular}{|c|c|c|c|c|}
\hline Township & District & Landing sites & Number of fishermen & $\%$ of fishermen \\
\hline \multirow[t]{3}{*}{ Goura } & Baya Mbedomo & Kogbedi & 54 & $10.95 \%$ \\
\hline & Lai & Naboui II & 70 & $14.20 \%$ \\
\hline & & Gbemboussa & 40 & $8.11 \%$ \\
\hline \multirow[t]{3}{*}{ Bétaré-Oya } & Yayoué & City Hall & 62 & $12.58 \%$ \\
\hline & & Pangara & 44 & $8.92 \%$ \\
\hline & Mbitom & Gbahoko & 23 & $4.67 \%$ \\
\hline \multirow[t]{2}{*}{ Belabo } & Képéré Deng-Deng & Wami & 200 & $40.57 \%$ \\
\hline & & Total & 493 & $100 \%$ \\
\hline
\end{tabular}


Table 2. Types of main fishing gears and their average anchoring time according to the landing site.

\begin{tabular}{cccc}
\hline $\begin{array}{c}\text { Average daily anchoring time of } \\
\text { the gear/fishermen (hours) }\end{array}$ & Gillnets & Longlines & Traps \\
\hline Fishermen landing site & 16 & 16 & 16 \\
\hline Kogbedi & 12 & 24 & 24 \\
Naboui II & 12 & 0 & 12 \\
Gbemboussa & 11 & 0 & 0 \\
City Hall & 15 & 14 & 16 \\
Pangara vanne & 17 & 17 & 17 \\
Wami & 16 & 0 & 24 \\
Gbahoko & & 17 & \\
\hline
\end{tabular}

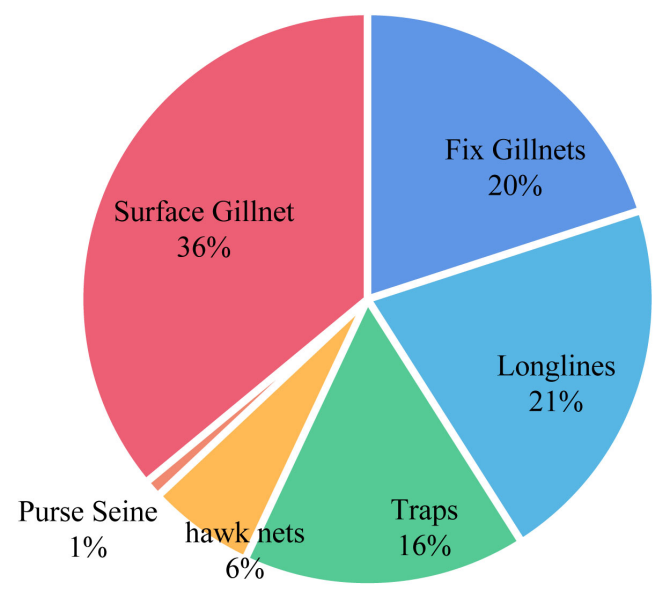

Figure 2. Fishing gears used in the Lom Pangar dam reservoir.

used fishing gear (56\%) and hawk net the least used (6\%) excluding purse seine (1\%) (Figure 2).

\subsection{Species Composition}

Lom Pangar hydroelectric dam reservoir has a total of 16 families and 37 fish species, with Cyprinius carpio and Clarias gariepinus being the most exploited and Sardinella aurita, least abundant species. Most species targeted in the seven sites are semi-pelagic and benthic. As shown in Table 3, Gbahoko and Naboui sites are the ones with the highest number of species while Wami is the site with the lowest number of species.

\subsection{Size Composition}

The measurements were carried out on the species landed on each site. The sizes of fish species landed, expressed in minimum and maximum length are presented in Figure 3 for each site. In the site of Naboui, the small fish sizes were observed on the Petrocephalus spp $(13 \mathrm{~cm})$ while the large fish sizes were observed 
Table 3. Fish species composition in Lom Pangar hydroelectric dam reservoir in the eastern region of Cameroon.

\begin{tabular}{|c|c|c|c|c|c|c|c|c|}
\hline \multirow{2}{*}{ Family } & \multirow{2}{*}{ Scientific name } & \multicolumn{7}{|c|}{ Local name } \\
\hline & & Kogbedi & Naboui & Gbemboussa & City hall & Pangara & Wami & Gbahoko \\
\hline \multirow{3}{*}{ Cichlidae } & Cyprinius carpio & carpe & carpe & carpe & carpe & carpe & carpe & carpe \\
\hline & Hemichromis bimaculatus & carpe blanche & & & carpe blanche & & & \\
\hline & Oreochromis niloticus & & & & & & & ndouksoudou \\
\hline \multirow{9}{*}{ Mormyridae } & Petrocephalus spp & & définy & & & & & famba \\
\hline & Marcusenius mento & & ghella & & & & & ghella \\
\hline & Petrocephalus simus & & ghella & & & & & ghella \\
\hline & $\begin{array}{c}\text { Campylomormyrus } \\
\text { tamandua }\end{array}$ & & & & & & & zokforo \\
\hline & Petrocephalus balayi & & ghella & & & & & ghella \\
\hline & Mormyrus spp & & tchitiawa & & & & & \\
\hline & Pollimyrus kingsleye & & & & & & & mbeta \\
\hline & Momyrops spp & & soudoumouka & & & & & \\
\hline & Brienomyrus spp & & & & & & & danga denge \\
\hline \multirow{3}{*}{ Alestidae } & Brycinus macrolepidotus & & ghotta & & & & & \\
\hline & Phenacogrammus major & & & ghotta & & & & \\
\hline & Alestes spp & & & & & gale au nez & & gale au nez \\
\hline \multirow{2}{*}{ Aridae } & Arius heudolitri & & machoiron & & & & & \\
\hline & Arius $s p p$ & & & poisson soleil & & & & \\
\hline Hepsetidae & Hepsetus odoe & $\begin{array}{l}\text { poisson } \\
\text { panthère }\end{array}$ & & & & $\begin{array}{l}\text { poisson } \\
\text { panthère }\end{array}$ & & \\
\hline \multirow{3}{*}{ Cyprinidae } & Barbus martorelli & queue rouge & queue rouge & queue rouge & queue rouge & queue rouge & & queue rouge \\
\hline & Barbus rainbaulti & & & & & & & gbota \\
\hline & Barbus spp & & gozoro & & & & & gozoro \\
\hline \multirow{5}{*}{ Claridae } & Clarias gariepinus & silure & silure & silure & silure & silure & silure & silure \\
\hline & Clarias pachynema & & silure noir & & & & & silure noir \\
\hline & Heterobranchus longifilis & & & & & & & bgebom \\
\hline & Clarias submarginatus & & silure blanc & & & & & \\
\hline & Clarias platycephalus & & silure tachete & & & & & \\
\hline \multirow{2}{*}{ Mochokidae } & Synodontis rebeli & & & & kpok-kpok & & & kpok-kpok \\
\hline & Synodontis spp & & & & & & & gougnet \\
\hline Bagridae & Chrysichthys nigroditatus & machoiron & machoiron & machoiron & machoiron & machoiron & & machoiron \\
\hline \multirow{2}{*}{ Characidae } & Hydrocynus foskali & & & & & & & gong \\
\hline & Hydrocynus vittatus & & & & & & & sa'a \\
\hline \multirow{2}{*}{ Channidae } & \multirow{2}{*}{ Parachanna obscura } & poisson & poisson & poisson & & poisson & poisson & poisson \\
\hline & & vipère & vipère & vipère & & vipère & vipère & vipère \\
\hline Polynamidae & Polydactylus quadrifilis & & avouri & & & faux capitaine & & avouri \\
\hline Clupeidae & Sardinella aurita & & sardine & sardine & & sardine & & sardine \\
\hline Shilbaedae & Schilbe mystus & & & & & & & salala \\
\hline Centropomidae & Lates niloticus & & & & & & & goboi \\
\hline \multirow{2}{*}{ Claroteidae } & Parauchenoglanis spp & & & & & poisson & & poisson \\
\hline & & & & & & militaire & & militaire \\
\hline
\end{tabular}



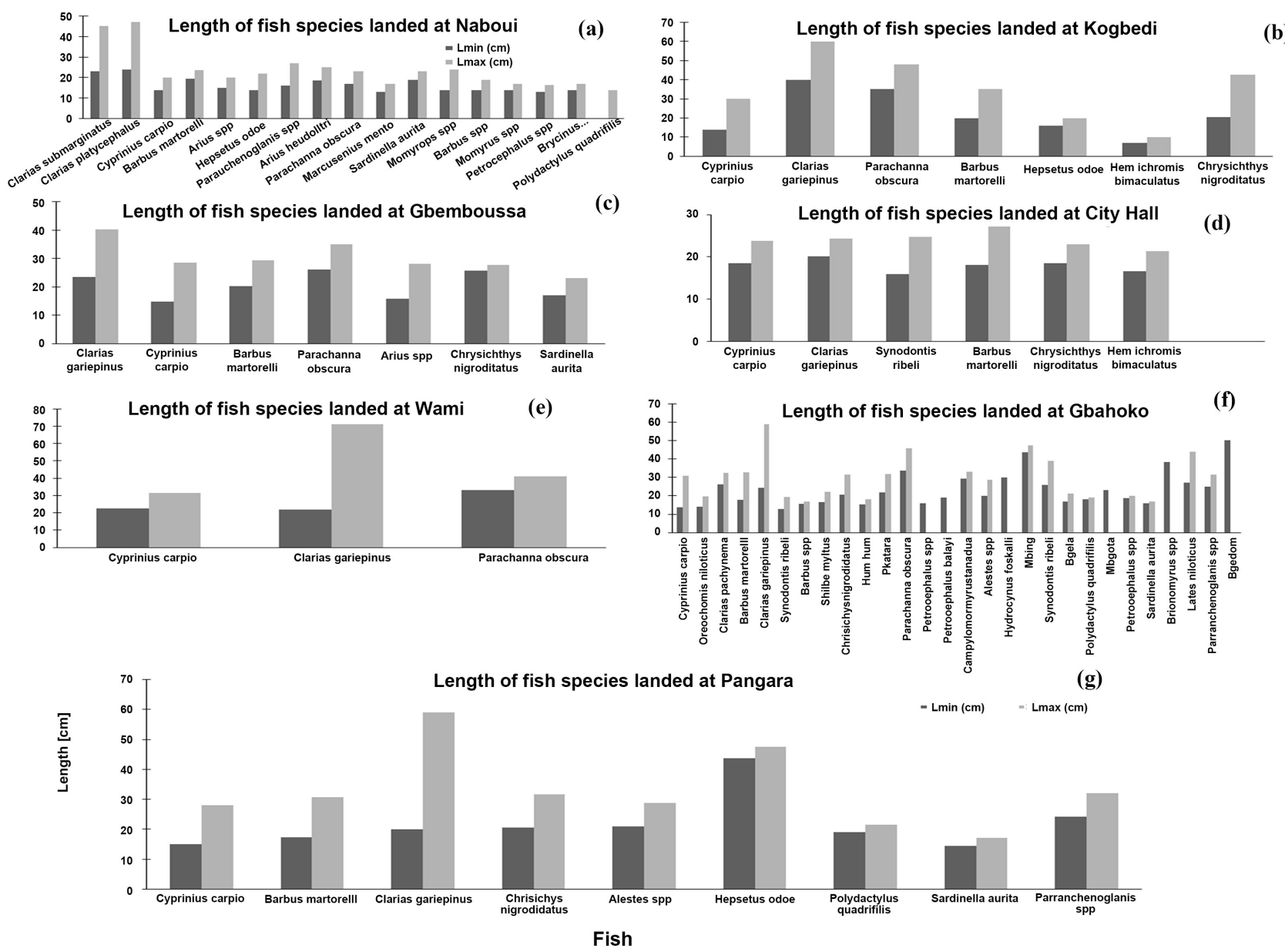

Figure 3. Fish size composition in each site.

on the Clarias platycephalus $(47 \mathrm{~cm})$. One may note that the Claridae family had longer lengths compared to the one of other species. The fish size ranged from 7 $\mathrm{cm}$ (Hemichromis bimaculatus) to $60 \mathrm{~cm}$ (Clarias gariepinus), $15.78 \mathrm{~cm}(C y$ prinus carpio) to $40.25 \mathrm{~cm}$ (Clarias gariepinus), $15.89 \mathrm{~cm}$ (Synodontis spp) to $27.22 \mathrm{~cm}$ (Barbus martorelli), $22.5 \mathrm{~cm}$ (Cyprinius carpio) to $71 \mathrm{~cm}$ (Clarias gariepinus), and from 12.72 (Synodontis rebeli) to $58.77 \mathrm{~cm}$ (Clarias gariepinus) in the sites of Kogbedi, Gbemboussa, City Hall, Wami, and Gbahoko, respectively.

\subsection{Quantity of Catches Landed}

The catches are landed in three forms such as fresh, salted or smoked fish. Quantities of fresh, dry and smoke main species of fish landed by site are shown on Table 4. As presented in Figure 4, the total catches landed in Lom Pangar hydroelectric dam reservoir were $78 \%, 9 \%, 4 \%, 2 \%$, and $1 \%$ for the sites of Wami, City Hall, Naboui, Kogbedi, Pangara, Gbemboussa, and Gbahoko respectively.

As shown in Figure 5, three main species of fish are smoked: Cyprinius carpio, Clarias gariepinus and Clarias camerounensis. Cyprinius carpio was the 
Table 4. Quantities of fresh, dry and smoke main species of fish landed by site.

\begin{tabular}{|c|c|c|c|c|}
\hline & Cyprinius carpio & Clarias gariepinus & Clarias camerounensis & \\
\hline Kogbedi & 68.00 & 36.00 & & 104.00 \\
\hline Wami & $40,476.00$ & $10,555.00$ & & $51,031.00$ \\
\hline City hall & 6305.00 & 591.00 & 931.00 & 7827.00 \\
\hline Gbahoko & 81.80 & 22.70 & & 104.50 \\
\hline Naboui & 436.90 & 2183.20 & & 2620.10 \\
\hline Pangara & 42.00 & 30.00 & & 72.00 \\
\hline Gbemboussa & 251.03 & 75.97 & & 327.00 \\
\hline TOTAL & $47,660.73$ & $13,493.87$ & 931.00 & $62,085.60$ \\
\hline Proportions & $76.77 \%$ & $21.73 \%$ & $1.50 \%$ & $100.00 \%$ \\
\hline
\end{tabular}

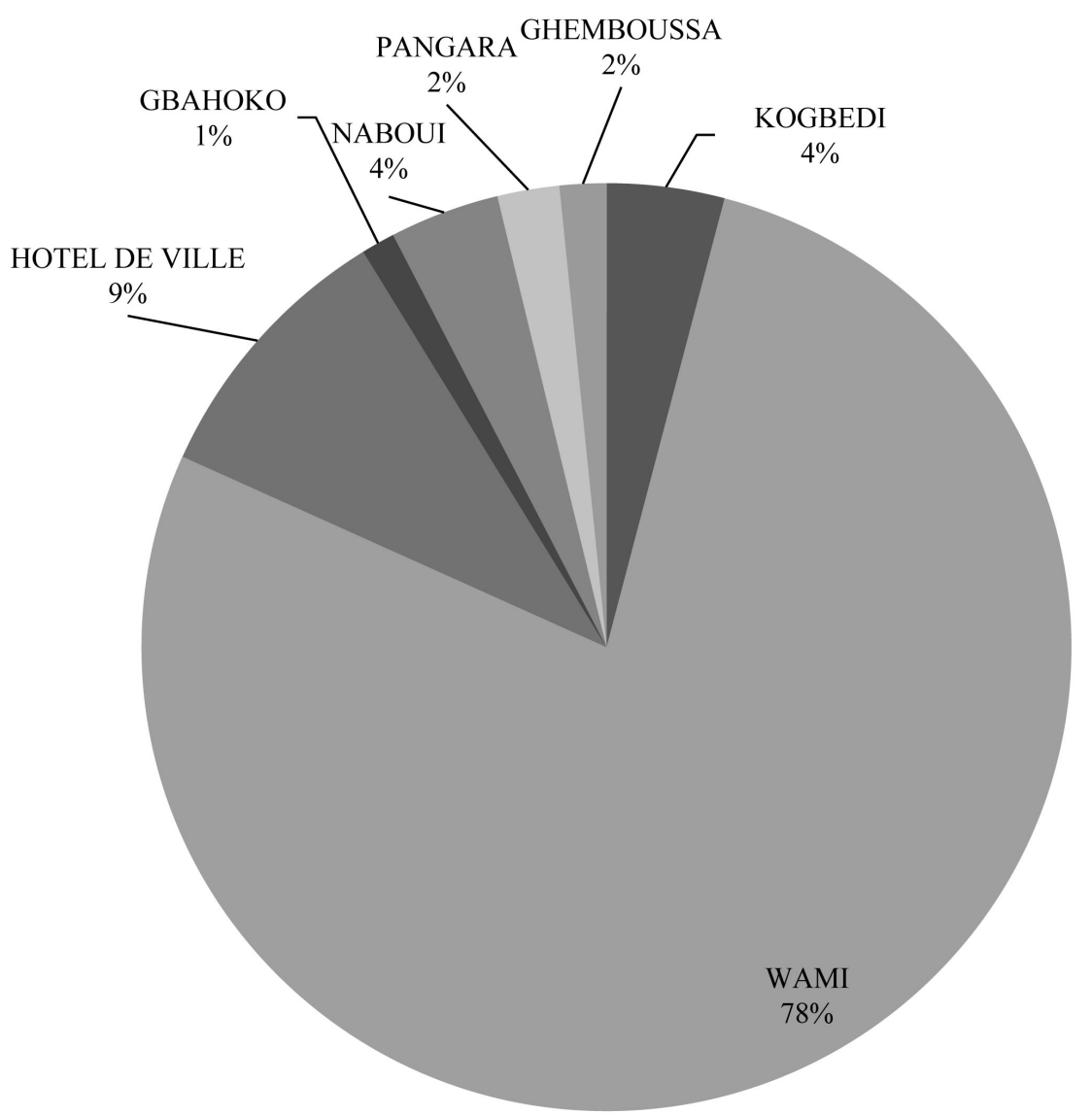

Figure 4. Quantities (kg) of fresh fish landed by site.

smokiest fish, which quantities were 40,476 kg and $6305 \mathrm{~kg}$ in the Wami and City Hall sites, respectively. Clarias gariepinus were captured only in the City hall site $(931 \mathrm{~kg})$.

Based on the collected data, the catches composition (catches quantity) was estimated as occurrence kilogram (Kg) for each species at each site (Figure 6). Cyprinius carpio represented the highest percentage of all species caught in all 
the sites except the Naboui site which is dominated by the catches of Clarias gariepinus. Indeed, Cyprinius carpio catches represented 87\%, 68\%, 82.01\%, $69.44 \%, 19.83 \%$, and $60.01 \%$ of total catches collected in the sites of Wami (d), Kogbedi (a), City Hall (c), Gbemboussa (b), Naboui (f), and Pangara (e), respectively. While, the Clarias gariepinus catches represented 13\%, 27\%, $7.31 \%$, $11.50 \%, 64.83 \%$, and $10.77 \%$ of total catches collected in the sites of Wami, Kogbedi, City Hall, Gbemboussa, Naboui, and Pangara, respectively.

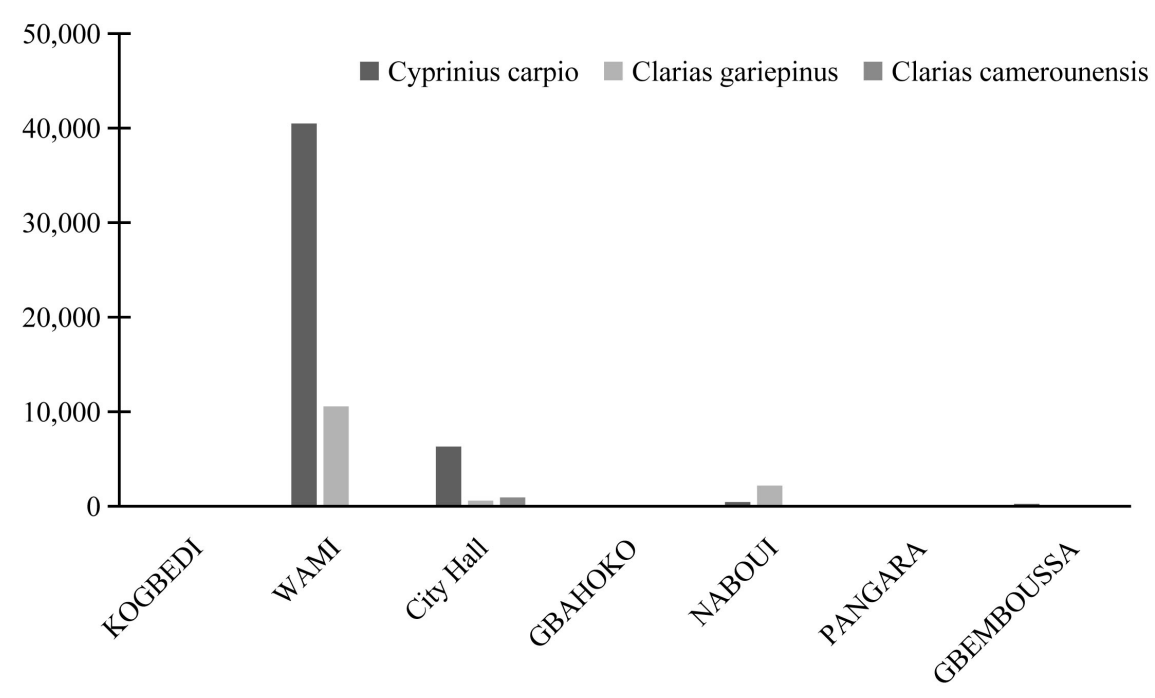

Figure 5. Total quantity (Kg) of smoked or dried fish landed by species and by landing site in September 2016.
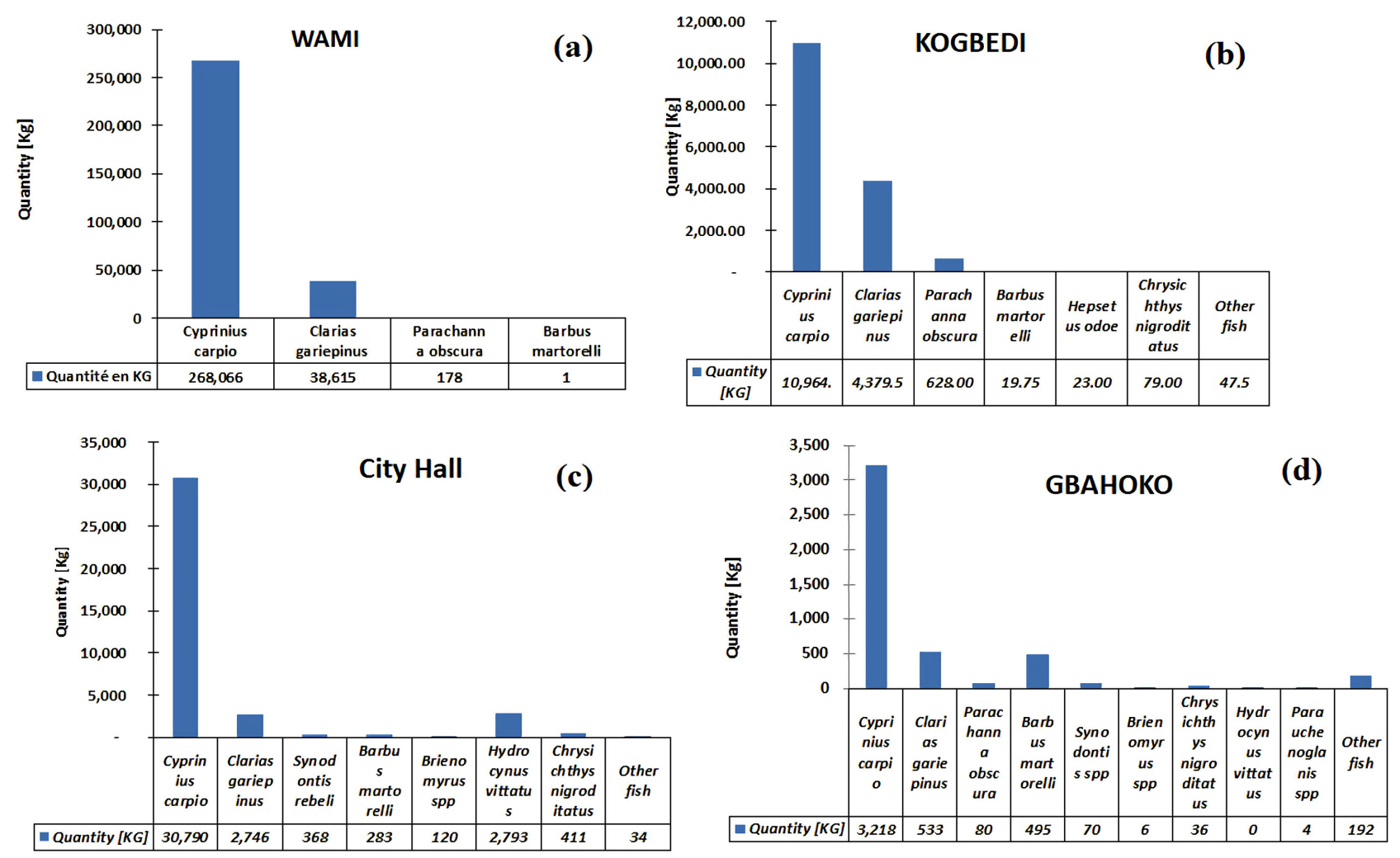

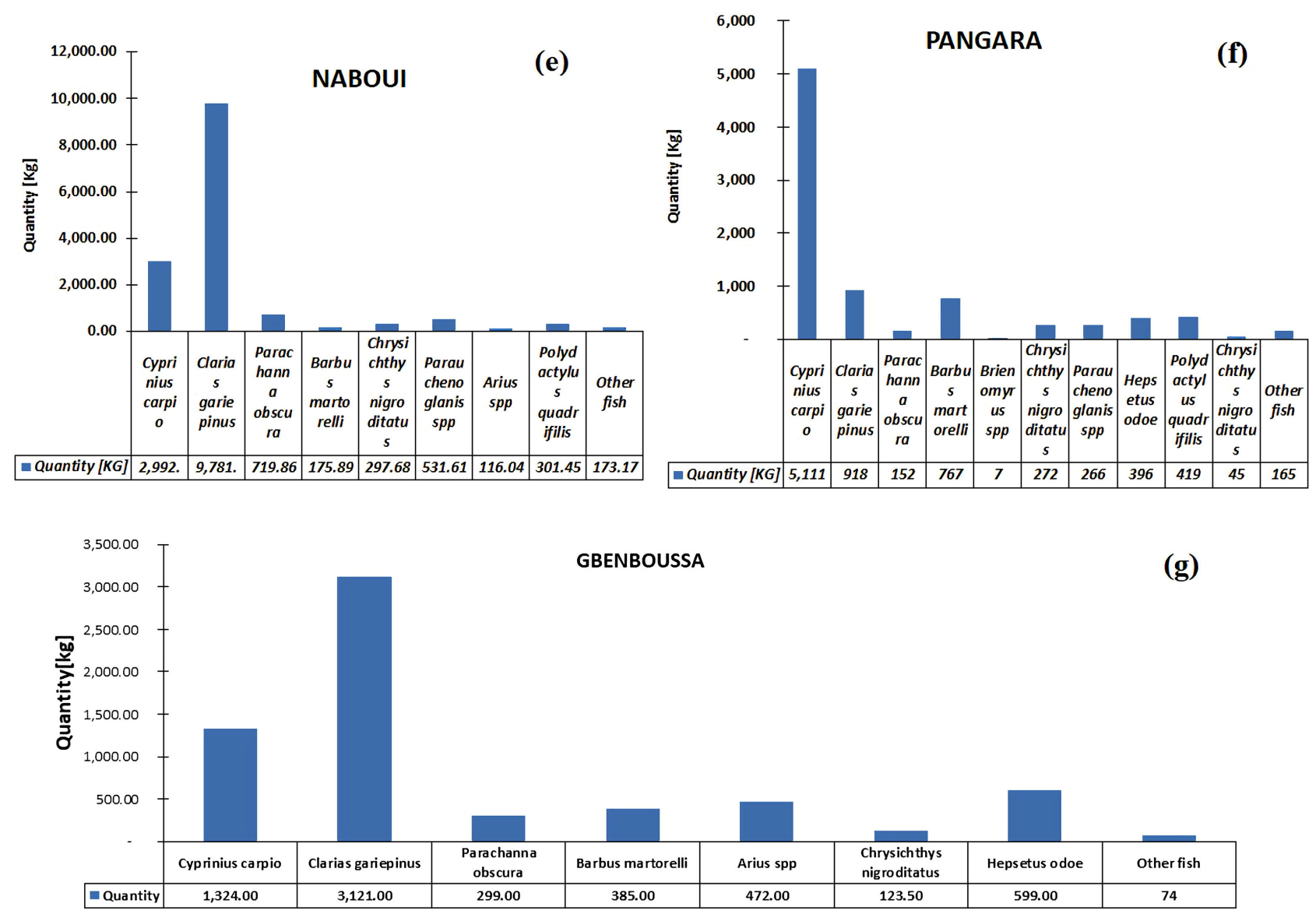

Figure 6. Catches composition (kg) by landing sites in September 2016.

Two families make up more than $96.8 \%$ of the catches landed in Lom Pangar hydroelectric dam reservoir, these are the Cichlidae (Cyprinius carpio) and Claridae (Clarias gariepinus). While others (Parachanna obscura, Barbus martorelli, Chrysichthys nigroditatus, Parauchenoglanis spp, Synodontis rebeli Hepsetus odoe, Arius spp etc. are represented as $3.2 \%$ of the total catch (Figure 7).

\section{Discussion}

Studies have shown that most African fishermen are more oriented towards artisanal fisheries (around 80 percent), which provides a source of food security and livelihood for many local communities [25]. Therefore, one of the main missions of sustainable fisheries management is to ensure the sustainability of fishery resources, to guarantee food security and respond to the demand for fishery resources while maximizing profiles [24] [26]. During the survey, it was found that the seven fish landing sites in the Lom Pangar hydropower dam reservoir employs more than 493 fishermen's and provides more than 623 tons of fishes for the Cameroonians.

However, the fish production from the Lom Pangar hydropower dam reservoir has gradually increased every year. The increase in production is due to the 


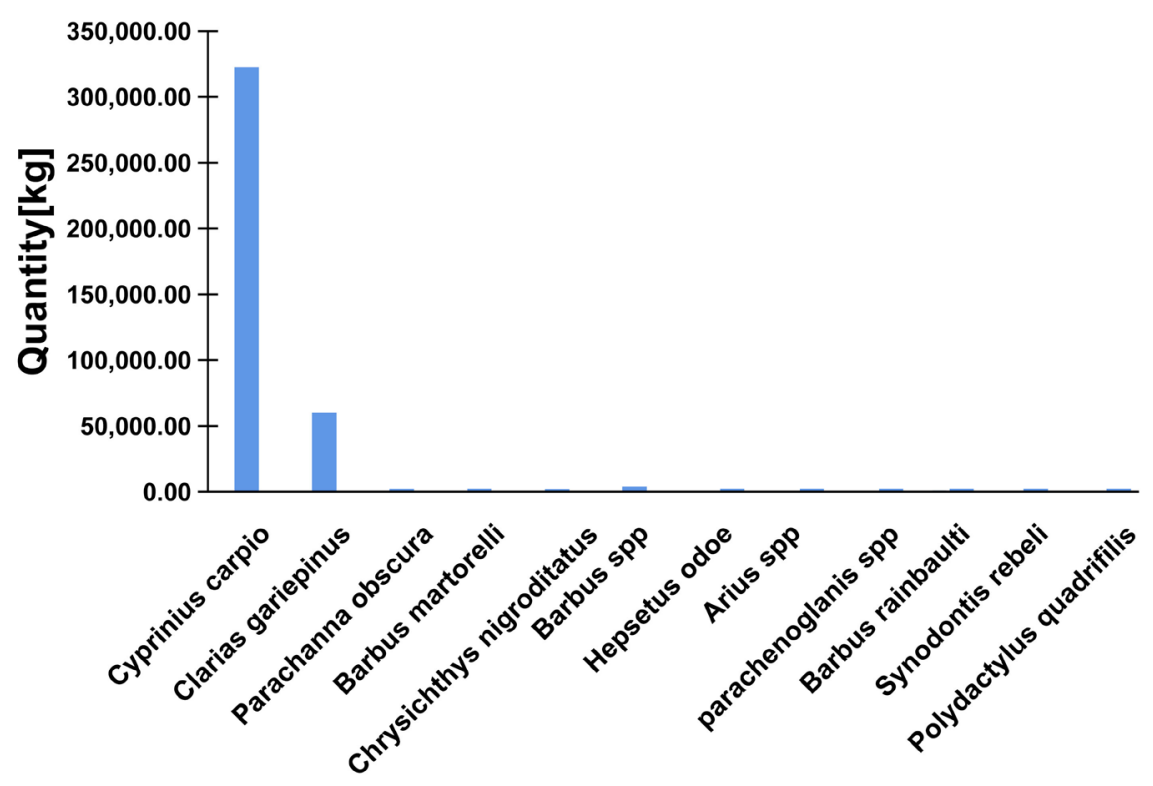

Figure 7. Most catch species in Lom Pangar hydroelectric dam reservoir in September 2016.

number of fishermen's increase every year. In addition is also because the Cameroonian government, through its policy of reducing imports and community development, has set up subsidies since 2016 allowing the population to settle in the area and practice fishing and agriculture. The factors that can influence this increase in production are climatic variations and water management. As presented above, the Wami site is the most frequented by fishermen. This site, located not far from the foot of the dam, is rich in water and consequently in fishery resources, hence the massive presence on this site of Mosgoun fishermen, very experienced in the practice of fishing. In addition, the proximity of the town of Belabo, easily accessible to sell the production, can also justify the abundant presence of fishermen in Wami [26].

Three main categories of fishing gears are used in the study area: gillnets, including surface drift gillnets and fixed gillnets; longlines and traps. Among these, surface drift gillnets, all monofilament, are the most used to target small pelagics (36\%) followed by fixed nets (20\%). Longlines occupy $21 \%$ while traps are used at around $16 \%$. The use of the hawk is marginal and only $6 \%$ of fishermen use this fishing gear in the reservoir. In general, these gears are selective for certain species and sizes of fish. Therefore, commercial fishermen apply their knowledge of gear selectivity to improve the efficiency of catching target species of specific sizes [27]. In the present study, these fishing gears were particularly selective for Cyprinius carpio and Clarias gariepinus. One of the reasons for their good selectivity is due to the fact that the control of the effort of these fishing gears is generally expressed in terms of a set of standard with time interval necessary for the management objectives and also due to the fact that they reduce the fish mortality [28].

The present investigation revealed that the fishermen of Naboui leave longli- 
nes and traps in the water for 24 hours. Likewise, Gbahoko fishermen can leave traps in the water at the same time. This is the longest anchorage time of a fishing gear in the reservoir. However, 37 species of fish belonging to 16 families were identified in the study area. The distribution of these species was 24 species landed in Gbahoko and 17 species in Naboui. Thus, Gbahoko and Naboui sites are the ones with the highest number of species, while three main fish species only are landed at the Wami site by fishermen during the period of study. This may be due to the transition from a riparian state to a lacustrine state during the formation of watercourses at other sites. It should be noted that five (5) species of fish are common at all landing sites, notably Cyprinius carpio, Barbus martorelli, Clarias gariepinus, Chrysichthys nigroditatus and Parachanna obscura (Table 4). The specie Brycinus macrolepidotus was only landed at the Naboui site during the period of study. It was shown in this study that the total quantity of fish landed in dried or smoked form during the impoundment study period was approximately 62 tonnes. Three species are predominant: Cyprinius carpio (77\%), Clarias gariepinus (22\%); Clarias camerounensis (1\%). Landings of the species clarias camerounensis have been recorded only in City Hall (0.93 tons). The most important landings were recorded in Wami (51 ton), then in City Hall (7.82 tons) and in Naboui (2.62 tons). It was in agreement with the results obtained by ENVIREP-CAM [16] in the dams (Lagdo, Mbakaou, Mape and Bamendjin, Maga dams), natural lakes (Lake Chad basin, Barombi, Ossa) and in rivers (Sanaga, Wouri, Mungo, Nyong, Doume, Logone, Ntem).

\section{Conclusion}

The impoundment of the Lom Pangar dam reservoir created favorable conditions for the development of fishing activities, practiced mainly by Mosgoun fishermen. The most commonly used fishing gears are gillnets, traps and longlines. These gears captured in September 2016 approximately 623 tons of fish, which constitutes a significant increase in Cameroon's fishery production, which is still heavily in deficit. The Wami site is by far the most productive with around 480 tons of fish landed during the study period. Cyprinus carpio was the most landed species among 37 species identified in the study area. In order to guarantee sustainable exploitation of the resources of this dam reservoir, further studies should be carried out on the fishing gear used, in particular on their selectivity.

\section{Acknowledgements}

This publication was undertaken in the framework of the Lom Pangar hydroelectric dam project, implemented by the Electricity Development Coorporation (EDC) under the support of the Netherlands Development Organisation (SNV) in Cameroon.

\section{Conflicts of Interest}

The authors declare no conflicts of interest regarding the publication of this paper. 


\section{References}

[1] Béné, C., Abban, E., Abdel-Rahman, S., Ayappan, S., Brummett, R., Dankwa, H. and Kolding, J. (2009) Improved Fisheries Productivity and Management in Tropical Reservoirs. CGIAR Challenge Program on Water and Food Project Report Series. CPWF Project, Number 34.

[2] Lom-pangar dam project (2011) Regional Development Plan; January 2011.

[3] Mensah, M.A. and Quaatey, S.N.K. (2002) An Overview of the Fishery Resources and Fishery Research in the Gulf of Guinea. Large Marine Ecosystems, 11, 227-239. https://doi.org/10.1016/S1570-0461(02)80039-8

[4] Ngok, E., Ndjamen, D. and Dongmo Jiongo, V. (2005) Contribution économique et sociale de la pêche artisanale aux moyens d'existence durables et à la réduction de la pauvreté. Rome, Programme pour des Moyens d'Existence Durables dans la pêche (PMEDP), Yaoundé. 41 p.

[5] Thierry, B.N.N., Kindong, R. and Xu, L.X. (2018) Reconstruction of Historical Fisheries Profile of Cameroon. International Journal of Fisheries Science and Research, 2, 1008.

[6] Djama, T. and Pitcher, T.J. (1989) Comparative Stock Assessment of Two Scianids Species: Pseudotolithus typus and Pseudotolithus senegalensis, Off-Cameroon. Fisheries Research, 7, 111-125. https://doi.org/10.1016/0165-7836(89)90011-8

[7] Djama, T. and Pitcher, T.J. (1997) The Differential Effects of Changing Management Regimes on Yields from Two Fisheries Exploiting the Same Resources. Fisheries Research, 29, 33-37. https://doi.org/10.1016/S0165-7836(96)00520-6

[8] Njock, J.C. (2000) GEF/UNEP/FAO Regional Workshop on Reducing the Impact of Tropical Shrimp Trawl Fisheries, Lagos, Nigeria, 15-17 December 1999. FAO Fisheries Report No. 627.

[9] Njock, J.C. (2001) Reducing the Impact of Tropical Shrimp Trawling Fisheries on the Living Marine Resources through the Adoption of Environmentally Friendly Techniques and Practice in Cameroon. FAO, Roma.

[10] Djama, T. (1992) Interaction between the Artisanal and Industrial Fisheries in Cameroon. PhD Thesis, University of Wales, Cardiff.

[11] Djama, T. (2004) Status of the Population Parameters of Pseudotolithus senegalensis of Cameroon. Journal of the Cameroon Academy of Sciences, 4, 93-98.

[12] MINEPIA Frame Survey (2009) Enquete cadre et socio-economique de la peche artisanale au Cameroon.

[13] MINEPIA, Reports (2014) Rapport Annuel d'activite de la delegation provinciale de l'elevage des pêches et industrie animale du littoral. Par Antoine Tchoubia.

[14] MINEPIA (2005) Projet Appui à la mise en place d'un système statistique informatisé pour la pêche artisanale Captures de la pêche continentale dans la province du Sud-Ouest.

[15] MINEPAT (2009) Loi de finances 2013, Ministère de l'Economie, de la Planification et de l'Aménagement du Territoire.

[16] ENVIREP-CAM (2011) Overview of Management and Exploitation of the Fisheries Resources of Cameroon, Central West Africa. Institut de Recherche Agricole pour le Développement, Yaoundé, $70 \mathrm{p}$.

[17] Onuoha, F.C. (2009) Environmental Degradation, Livelihood and Conflicts: A Focus on the Implications of the Diminishing Water Resources of Lake Chad for North-Eastern Nigeria. African Journal on Conflict Resolution, 8, 35-62. 
https://doi.org/10.4314/ajcr.v8i2.39425

[18] Ssentongo, G.W. and Njock, J.C. (1987) Marine Fishery Resources of Cameroon: A Review of Exploited Fish Stocks. CECAF/ECAF Series 87/44, 71 p.

[19] Total E \& P, Socio-Economic Baseline Study Exploration Drill Bomana Disoni. 167 p.

[20] N’Souvi, K., Sun, C., Egbendewe-Mondzozo, A., Kafui Tchakah, K. and Alabi-Doku, B.N. (2020) Analysis of the Impacts of Socioeconomic Factors on Hiring an External Labor Force in Tilapia Farming in Southern Togo. Aquaculture and Fisheries. https://doi.org/10.1016/j.aaf.2020.07.010

[21] Stiassny, M.L.J., Teugels, G.G. and Hopkins, C.D. (2007) Poissons d'eaux douces et saumâtres de basse Guinée, oust de l'Afrique centrale. Volumes 1 (800pp) and 2 (603pp), IRD Éditions, Paris.

[22] Froese, R., Stern-Pirlot, A., Winker, H. and Gascuel, D. (2008) Size Matters: How Single-Species Management Can Contribute to Ecosystem-Based Fisheries Management. Fisheries Research, 92, 231-241. https://doi.org/10.1016/j.fishres.2008.01.005

[23] Vincent, B. and Jacques, B. (2009) Guide de la mensuration des poissons, mollusques, crustacés et mammifères marins en halieutique. Archimer, Ifremer.

[24] El-Far, A., Aly, W., El-Din El-Haweet, A., Nasr-Allah, A. and Karisa, H. (2020) Fisheries Management Based on Gear Selectivity of a Tropical Reservoir, Lake Nasser, Egypt. Egyptian Journal of Aquatic Research, 46, 71-77. https://doi.org/10.1016/j.ejar.2020.02.004

[25] Lévêque, C. and Paugy, D. (1999) Les poissons des eaux douces continentales africaines. Diversité, écologie, utilisation par l'homme. Editions de l'IRD, Paris, 515 p.

[26] Magnet, C. and Pouomogne, V. (2005) Etude environnementale du barrage de Lom Pangar. Rapport ARSEL.

[27] Hubert, W., Pope, K. and Dettmers, J. (2012) Passive Capture Techniques. In: Zale, A.V., Parrish, D.L. and Sutton, T.M., Eds., Fisheries Techniques, 3rd Edition, American Fisheries Society, Bethesda, 223-265.

[28] Cochrane, K. (2002) A Fishery Manager's Guidebook-Management Measures and Their Application. Fisheries Technical Paper 424. FAO, Rome, 231.

[29] Tiosop (2005) Fishery Inventory and Socio Economic Analysis of the Sanaga River. World Fish Centre Research Project on Fisheries Information Monitoring Systems, $17 \mathrm{p}$. 